\title{
Transfer of Small Plasmid DNA Fragments from Polyacrylamide Gels onto Nitrocellulose Paper
}

\author{
Philippe Frossard, Kenneth L. Sisco, and Donald L. Rucknagel \\ Departments of Human Genetics and Internal Medicine, Simpson Memorial Institute. \\ University of Michigan Medical School, Ann Arbor, Michigan 48109
}

Received December 20, 1982

\begin{abstract}
The incorporation into a $7 \%$ polyacrylamide gel of a nucleic acid-specific photochemical reagent 4,5',8-trimethylpsoralen at a concentration of $1 \mathrm{mg} / \mathrm{dl}$ of acrylamide solution improves both the sensitivity and the efficiency of the transfer of plasmid DNA fragments from the gel onto nitrocellulose filters. This improvement allows detection by blot hybridization of DNA fragments as small as 57 bp long.

KEY WORDS: Southern transfer; blot hybridization; psoralen; plasmids; DNA; restriction enzymes.
\end{abstract}

The blot-hybridization method (1) is among the more extensively used techniques in nucleic acid research. This technique is limited in detecting DNA fragments smaller than 400 base pairs (bp), however. We show in this report that the incorporation of a psoralen derivative, $4,5^{\prime}, 8$-trimethylpsoralen (TMP), ${ }^{1}$ in the resolutive gel improves the transfer of 50 to 500-bp-long plasmid-DNA fragments onto nitrocellulose filters.

Psoralen and its derivatives are furocoumarins which intercalate with DNA in the dark in a manner similar to other polycyclic aromatic hydrocarbons such as acridine orange, ethidium bromide, or actinomycin. When intercalation is followed by near-uv light irradiation (UV-A; $\lambda \sim 360 \mathrm{~nm}$ ), the excited psoralen molecules then bind covalently to the pyrimidine bases of the DNA $(2,3)$. Psoralens can form complexes not only with double-stranded DNA, but also with RNA or single-stranded DNA (3).

The psoralens have been used clinically for treatment of patients with photosensitive or pigmentation skin disorders (4), or for diseases characterized by proliferative cell growth, i.e.,

${ }^{1}$ Abbreviation used: TMP, 4,5',8-trimethylpsoralen. in psoriasis. In DNA research they constitute useful photochemical probes for studying chromatin structure $(5,6)$ or examining the dynamics of secondary structure in DNA and RNA (7-9).

\section{MATERIALS AND METHODS}

Samples preparation. pBR 322 plasmid (BRL Laboratories) was cul with HaellI restriction endonuclease (Lyphozyme from BRL) according to the manufacturer's recommendations; 10-ng samples of HaelII-digested pBR 322 were submitted to electrophoresis, together with $20 \mu \mathrm{g}$ of sonicated carrier DNA (calf thymus or salmon sperm DNA, Sigma Chemical Co.).

Polyacrylamide gel electrophoresis. Electrophoresis was performed on $20 \times 15 \times 0.3-$ $\mathrm{cm}$ vertical polyacrylamide gels $(\mathrm{T}=7 \%$; $=5 \%$ ) in a $50 \mathrm{~mm}$ Tris- $\mathrm{HCl}, 50 \mathrm{~mm}$ borate buffer, pH 8.3, containing 2 mM EDTA, at 750 to $950 \mathrm{~V}-\mathrm{h}$. The procedure was performed in ambient light since the glass plates filtered out activating light. TMP (Trioxsalen, Sigma Chemical Co.), in alcoholic solution (120 $\mu \mathrm{g}$ $\mathrm{ml}^{-1}$ ) for amounts smaller than $1 \mathrm{mg}$ or as powder for amounts greater than $1 \mathrm{mg}$, was 
dissolved in the acrylamide solution just before polymerization at concentrations ranging from $200 \mu \mathrm{g}$ to $12 \mathrm{mg} \mathrm{TMP} / \mathrm{dl}$ of acrylamide solution. Extreme caution should be used in handling TMP due to its potent mutagenicity and carcinogenicity.

Gel treatment and transfer. After electrophoresis the DNA fragments were denatured by soaking the gel in a $0.5 \mathrm{M} \mathrm{NaOH}, 1.5 \mathrm{M}$ $\mathrm{NaCl}$ solution for $30 \mathrm{~min}$, followed by neutralization in $1 \mathrm{M}$ Tris- $\mathrm{HCl}, 3 \mathrm{M} \mathrm{NaCl}, \mathrm{pH}$ 7.4, for $30 \mathrm{~min}$. These two steps (alkaline denaturation and neutralization of the DNA fragments) were carried out in the dark. The gels were then exposed to ambient laboratory light for various periods of time before the blotting procedure, which was performed by electroelution of the DNA fragments onto nitrocellulose filters (Schleicher and Schuell; $\mu$ $=0.1 \mu \mathrm{m}$ ) in a Trans-Blot cell (Bio-Rad Laboratories) or comparable apparatus at $30 \mathrm{~V}$ for $3 \mathrm{~h}$; the electrotransfer buffer was $50 \mathrm{mM}$ Tris- $\mathrm{HCl}, 50 \mathrm{~mm}$ borate, $\mathrm{pH} 8.3$, containing $2 \mathrm{mM}$ EDTA. Ethidium bromide staining must be done with a guide strip or on a second electrophoresis. After denaturation and neutralization in the dark, the gels were exposed to ambient light for varying periods of time while being loaded into the holder in which they are pressed against the nitrocellulose membrane. Electroelution is then done in ambient light.

Hybridization and autoradiography. Baking, prehybridization, hybridization, and washing of the filters was done according to Jeffreys and Flavell (10). As a probe, $100 \mathrm{ng}$ of nick-translated pBR 322 plasmid with a

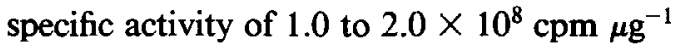
were used per filter. The position of the bands was revealed by autoradiography using $X$ Omat AR-Xray films (Kodak) and intensifying screens (Cronex X-ray screens, Dupont).

\section{RESULTS}

In Figure 1 are presented the autoradiographs of HaelII-digested pBR 322 showing a comparison of the results obtained without
TMP (Fig. 1A) and with increasing amounts of TMP incorporated in the polyacrylamide gels (Figs. 1B-D). Incorporating TMP into the polyacrylamide gels before electrophoresis clearly has an effect on the pattern obtained upon autoradiography; the optimal results (i.e., more intense as well as smaller detectable bands) are obtained when TMP is used at a concentration of $1 \mathrm{mg} / \mathrm{dl}$ of acrylamide solution (Fig. 1D). Further increasing the TMP concentration, from 2 to $12 \mathrm{mg}$ TMP/dl of acrylamide solution (the last value corresponding to the solubility limit of TMP in aqueous medium) leads to patterns less intense than Fig. 1D to barely visible under the same conditions of exposure (data not shown).

In Figure 2, the DNA fragments were submitted to $7 \%$ polyacrylamide gel electrophoresis in the presence of $1 \mathrm{mg} \mathrm{TMP/dl}$ of acrylamide solution, with varying times of exposure of the gels to ambient light between the end of the denaturation-neutralization steps (carried out in the dark) and the electroblotting of the fragments. The optimal exposure is $30 \mathrm{~s}$ to $1 \mathrm{~min}$ (Figs. $2 \mathrm{C}$ and $\mathrm{D}$ ). The shortest observable fragments are 57 , and occasionally 51, bp long. Although near-uv irradiation facilitates covalent cross-linkage of DNA fragments, psoralen in the complete absence of light mediates the reaction slightly, giving more intense and more complete patterns than in the case of experiments carried out without the presence of TMP.

In an attempt to detect smaller size fragments (for example, the 21-bp fragment present in the HaelII-digest of pBR 322), we used 10 to $12 \%$ polyacrylamide gels, but the smallest detectable fragments remained in the 51 to 57-bp range. Under these conditions, the observed patterns were always suboptimal.

Adding carrier DNA ( $20 \mu \mathrm{g}$ of sheared calf thymus or salmon sperm DNA) to the digested plasmid when loading the samples for electrophoresis enhanced the intensity of the patterns obtained upon autoradiography, which appeared to be true whether TMP was used or not. 
A $\quad$ B $\quad$ C $\quad$ D

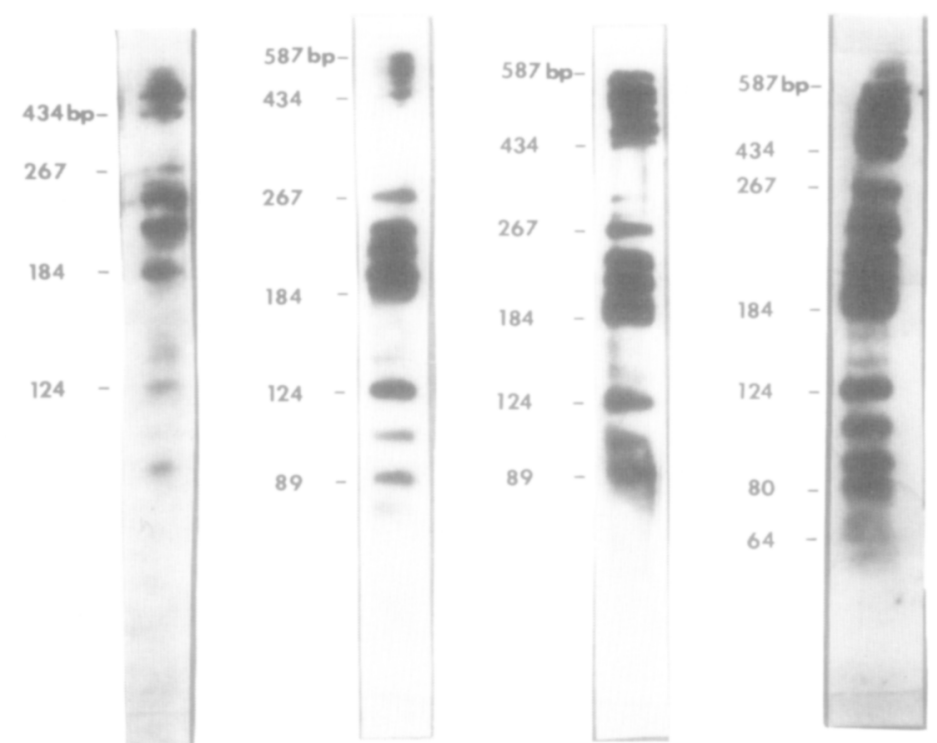

Fig. 1. Autoradiographs of HaelI digests of pBR322 submitted, together with $20 \mu \mathrm{g}$ of sheared calf thymus DNA, to electrophoresis in a 7\% polyacrylamide gel. (A) without TMP; (B), (C) and (D) with 250 $\mu \mathrm{g}, 400 \mu \mathrm{g}$, and $1 \mathrm{mg} \mathrm{TMP} / \mathrm{dl}$ acrylamide solution, respectively. Electrotransfer was performed as described in the text after exposure of the gels to light for $30 \mathrm{~s}$. Autoradiographs were exposed for $6 \mathrm{~h}$.

\section{DISCUSSION}

We have established that the use of TMP in a $7 \%$ polyacrylamide gel improves the electroblotting of plasmid DNA fragments, leading to more intense patterns upon autoradiography and allowing visualization of fragments as small as $\mathbf{5 7}$ bp long. Optimal results are obtained when DNA fragments are submitted to electrophoresis in a gel containing $1 \mathrm{mg}$ $\mathrm{TMP} / \mathrm{dl}$ of acrylamide solution (this step is carried out in ambient light), denatured and neutralized in the dark, and then submitted to ambient light for $30 \mathrm{~s}$ to $1 \mathrm{~min}$ before being electrotransferred. The last step can be performed at ambient light. Photography after electrophoresis is avoided; a parallel electrophoresis is required if this is desired.

These results do not allow us to explain the mechanism of action of TMP in these exper- iments and we can only propose some hypotheses. TMP, for example, does not seem to act during the course of electrophoresis since discrete bands are obtained and the patterns are similar whether TMP is used or not. One possible mechanism is that small fragments are cross-linked into larger networks that transfer efficiently and bind to the nitrocellulose membrane. This mechanism is supported by the fact that excess psoralen, thereby increasing the size of the network, appears to diminish the efficiency of the procedure. Similarly, excessive exposure to light may produce networks too large to transfer. We cannot exclude the possibility that 3,4-monocycloadducts are formed between TMP and partially denatured DNA fragments in the polyacrylamide gel upon light irradiation; these monocycloadducts might then transfer and the other reactive group $\left(4^{\prime}, 5^{\prime}-\mathrm{C}=\mathrm{C}\right.$ bonds) of 

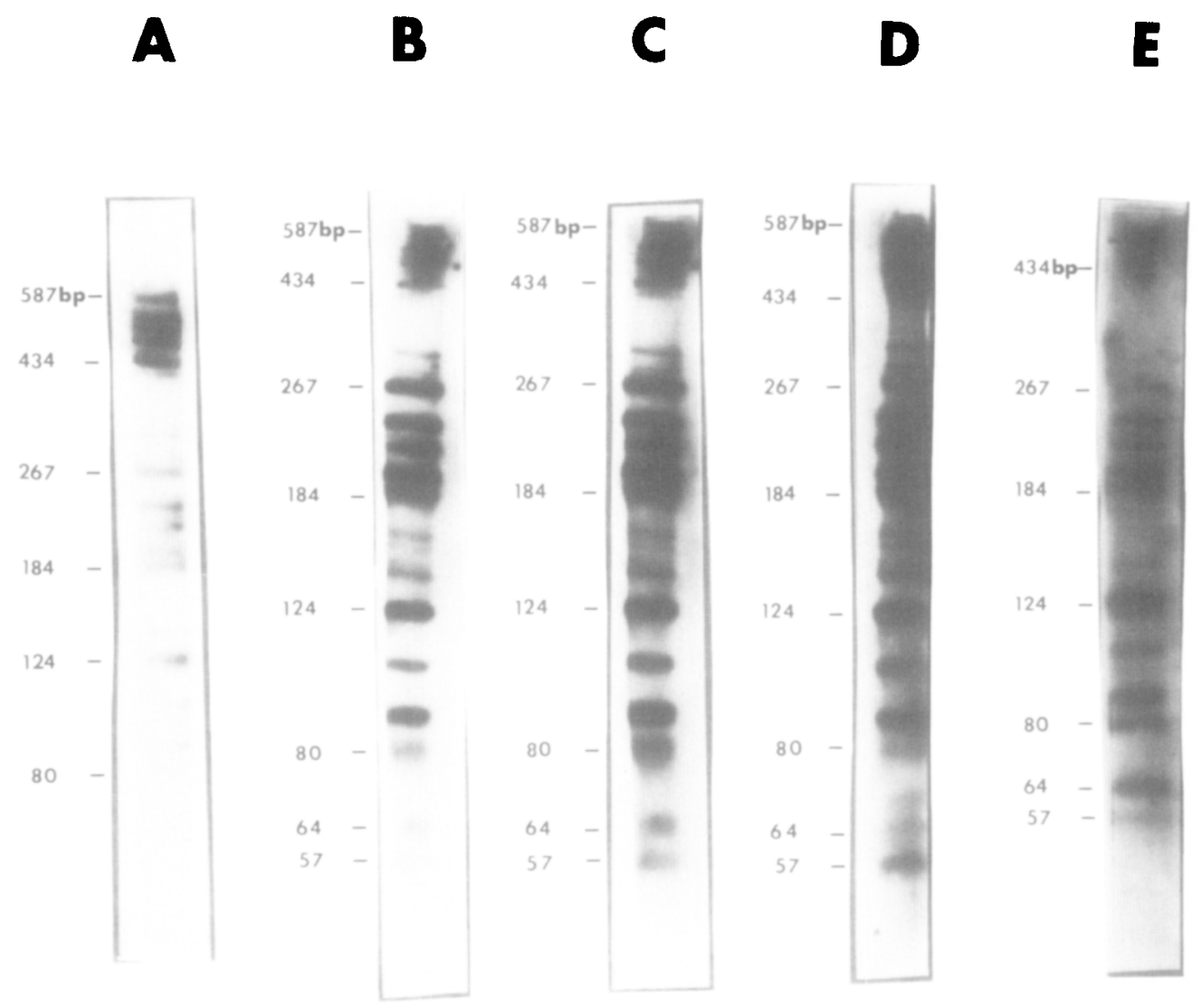

FIG. 2. Six-hour exposed autoradiographs of HaellI-digested pBR322 submitted, together with $20 \mu \mathrm{g}$ of sheared calf thymus DNA, to electrophoresis in a 7\% polyacrylamide gel containing $1 \mathrm{mg}$ TMP/dl acrylamide solution. Electrotransfer was performed after exposure of the gels to light for $0 \mathrm{~s}$ (A), $10 \mathrm{~s}$ (B), $30 \mathrm{~s}$ (C), 1 $\min (\mathrm{D})$, and $10 \mathrm{~min}(\mathrm{E})$.

TMP bind with the nitrocellulose matrix. Darkness appeared to be essential only during the denaturation-neutralization steps. Most likely that is because the glass plates and plastic apparatus in which the electrophoreses and electrotransfer are performed filtered out the near-uv light.

All hypothescs remain open and require further investigation. The aim of this report is to present a simple method allowing the visualization of 50- to 500-bp-long plasmidDNA fragments.

\section{ACKNOWLEDGMENTS}

Supported by a Clinical Research Grant from the National Foundation-March of Dimes and U.S.P.H.S. NIHRO1-AM-20964 and T32-AM-07359.

\section{REFERENCES}

1. Southern, E. M. (1975) J. Mol. Biol. 98, 503-517.

2. Cole, R. S. (1970) Biochim. Biophys. Acta 217, 3039.

3. Song, P. S., and Ou, C. N. (1980) Ann. N. Y. Acad. Sci. 346, 355-367.

4. Fitzpatrick, T. B., Arndt, K. A., El Mofty, A. M., and Pathak, M. A. (1966) Arch. Dermatol. 93, 589600.

5. Wiesehahn, G. P., Hyde, J. E., and Hearst, J. E. (1977) Biochemistry 16, 925-932.

6. Cech, T., and Pardue, M. L. (1977) Cell 11, 631640.

7. Cassuto, E., Gross, N., Bardwell, E., and HowardFlanders, P. (1977) Biochim. Biophys. Acta 475, 589-600.

8. Schen, C. K., Hsieh, T. S., Wang, J. C., and Hearst, J. E. (1977) J. Mol. Biol. 116, 661-679.

9. Cantor, C. R. (1980) Ann. N. Y. Acad. Sci. 346, 349356.

10. Jeffreys, A. J., and Flavell, R. A. (1977) Cell 12, 429439. 